\title{
PENINGKATAN HASIL BELAJAR IPS DAN SELF ESTEEM SISWA SD MELALUI MULTIMEDIA DALAM PEMBELAJARAN IPS
}

\author{
(Penelitian Kuasi Eksperimen di Kelas IV SDN \\ di Kecamatan Cibiru-Bandung)
}

Tin Rustini ${ }^{1}$

\begin{abstract}
ABSTRAK
Penelitian ini bertujuan untuk membandingkan peningkatan hasil belajar IPS dan self esteem siswa yang pembelajarannya menggunakan multimedia dan konvensional. Penelitian ini adalah penelitian kuantitatif dengan metode kuasi eksperimen dan desain yang digunakankelompok kontrol non ekivalendengan instrumen penelitian yang digunakan berupa tes hasil belajar IPS dan non-tes (self esteem). Data yang dianalisis adalah data pretes, postes, dan n-gain. Hasil penelitian menunjukkan bahwa peningkatan hasil belajar IPSdan self esteem siswa setelah mendapatkan pembelajaran dengan multimedia lebih baik dibandingkan dengan siswa yang mendapatkan pembelajaran IPS secara konvensional; Tidak terdapat hubungan yang positif antara hasil belajar IPS siswa dan self esteem siswa dalam pembelajaran yang menggunakan pembelajaran dengan multimedia.

Kata Kunci: Multimedia, Hasil Belajar IPS, Self Esteem
\end{abstract}

\section{A. PENDAHULUAN}

Keberhasilan proses pembelajaran merupakan hal utama yang didambakan dalam melaksanakan pendidikan di sekolah. Salah satu parameter keberhasilan yang dicapai seseorang adalah prestasi belajar akademik. Kenyataannya, hasil belajar IPS kurang memuaskan. Salah satu alasannya, karena pada pembelajaran IPS sebagian besar guru melaksanakan proses belajar mengajar hanya untuk mentransfer pengalamannya dan masih banyak guru yang menggunakan metode ceramah. Sehingga terkesan monoton dan membuat siswa jenuh. Pada kenyataannya metode ceramah hanya guru yang berperan aktif dalam proses belajar, siswa cepat tanggap dan cepat pula lupa dan mengakibatkan timbulnya rasa bosan, ngantuk bahkan kurang bersemangat dalam belajar.

Peningkatan hasil belajar IPS bagi peserta didik sangat diperlukan untuk mengembangkan dirinya menyongsong masa depan yang penuh tantangan. Agar peserta didik memiliki kemampuan IPS yang layak diperlukan model pembelajaran yang memadai dan relevan dengan standar kompetensi mata pelajaran IPS itu sendiri (Depdiknas, 2004:03).

Di samping banyaknya penelitian dalam aspek kognitif, aspek afektif mulai ditelaah para peneliti, antara lain: self esteem siswa yang diperikirakan dapat meningkatkan hasil belajar siswa. Self-esteem merupakan salah satu komponen afektif yang harus diperhatikan dalam dunia pendidikan. Istilah self-esteem diartikan pula sebagai kepercayaan diri atau keyakinan diri. Self-esteem berkaitan dengan perasaan

\footnotetext{
${ }^{1}$ Dosen UPI Kampus Cibiru. Alamat Surel: tinrustini@yahoo.com
} 
bahwa kita pantas, layak, berharga, mampu dan berguna. Self-esteem adalah penilaian tinggi atau rendah yang dibuat individu tentang hal-hal yang berkaitan dengan dirinya yang menunjukkan bahwa sejauh mana individu tersebut menyukai dirinya sebagai individu yang mampu, penting dan berharga.

Dengan demikian, peranan guru sebagai seorang pendidik dituntut untuk dapat mengatasi hal tersebut dengan penggunaan multimedia yang bersifat mengembangkan keaktifan siswa, menjadikan siswa lebih berkonsentrasi pada mata pelajaran IPS sehingga menghasilkan proses pembelajaran siswa dan hasil belajar yang optimal. Pada kenyataannya hampir setiap sekolah sudah terdapat berbagai media pembelajaran yang dapat membantu guru dalam melaksanakan proses pembelajaran, tetapi kurang dapat memanfaatkan fasilitas tersebut.

Untuk menumbuh kembangkan hasil belajar dan self esteem siswa diperlukan suatu pembelajaran yang mampu menumbuhkan hasil belajar IPS dan self esteem siswa. Dalam proses pembelajaran, guru memiliki peran untuk memilih model dan media pembelajaran yang tepat sesuai dengan materi yang disampaikan demi tercapainya tujuan pendidikan. Pembelajaran yang dipandang sukses harus berorientasi pada siswa sehingga siswa dipandang sebagai titik pusat terjadinya proses belajar sebagai subjek yang berkembang melalui pengalaman belajar, hal ini dilakukan untuk membangkitkan aktivitas siswa dalam pembelajaran. Pencapaian tujuan pendidikan IPS khususnya di sekolah dasar dapat berhasil dengan baik apabila mengacu dari ketiga aspek ranah, yaitu kognitif, afektif, dan psikomotorik. Karakter siswa yang memiliki rasa ingin tahu tinggi menjadikan guru harus lebih kreatif menggunakan berbagai metode, model serta media selama pembelajaran.

Penggunaan media pembelajaran menjadi sangat penting, dikarenakan sesuai dengan tahap perkembangan siswa yang masih berpikir operasional konkret yang sesuai dengan teori dari Piaget (Dahar, 1988:154) menyatakan bahwa'anak memiliki operasi-operasi logis yang dapat diterapkannya pada masalah-masalah konkret.' Dengan penggunaan media pembelajaran dapat memberikan pengalamanpengalaman lebih konkrit pada siswa serta merangsang aktivitas siswa untuk belajar dan menemukan sendiri pengetahuannya. Penggunaan media juga dibutuhkan untuk mengatasi permasalahan yang muncul dalam proses pembelajaran karena keterbatasan waktu, tempat dan benda. Selain itu penggunaan media dapat mengarahkan pola pemikiran siswa yang tadinya bersifat abstrak menjadi konkret.

Dari sekian banyak media yang dapat dimanfaatkan selama pembelajaran IPS di SD, penggunaan multimedia dapat membantu mengkonkretkan konsep IPS yang abstrak. Multimedia itu sendiri adalah perpaduan berbagai macam media. Sebagai guru yang tak boleh lepas dari teknologi untuk mendidik para siswanya, mengharuskan penggunaan multimedia menjadi salah satu cara meningkatkan hasil pembelajaran IPS. Rohman (2008) yang merupakan salah seorang peneliti mengatakan bahwa "pembelajaran dengan komputer multimedia dapat digunakan sebagai alat bantu dalam proses belajar sebagai stimulus untuk meningkatkan hasil belajar siswa di kelas." Dari penelitian yang beliau lakukan, penggunaan multimedia dapat meningkatkan hasil belajar siswa.

Guru perlu menggunakan multimedia selain memfokuskan perhatian siswa, adalah sebagai salah satu cara menyampaikan pesan kepada siswa sehingga 
pembelajaran lebih bermakna. Peran multimedia sudah terlihat jelas dari penggunaannya dalam pembelajaran IPS yang mana dapat menyampaikan pesan pembelajaran lebih menarik, dan dirasakan mudah untuk diterapkan kepada siswa. Penggunaan multimedia bagi siswa juga dapat menggali konsep dan memahami suatu konsep dari bahan ajar dengan keterlibatan langsung dari siswa itu sendiri selama kegiatan pembelajaran.

Ada beberapa keuntungan dalam pembelajaran menggunakan multimedia ini, antara lain siswa sepenuhnya berkonsentrasi dan berpartisipasi dalam proses belajar, setiap siswa dapat melakukan kegiatan belajar dengan kesempatan sesuai dengan kemampuan masing-masing dan lebih aktif selama kegiatan pembelajaran. Karena dari keterlibatan langsung dalam penggunaan multimedia selama kegiatan pembelajaran menjadikan siswa lebih aktif.

Berdasarkan latar belakang masalah yang telah diuraikan di atas, maka rumusan masalah dalam penelitian ini adalah: (1) Apakah peningkatan hasil belajar IPS siswa setelah mendapatkan pembelajaran dengan multimedia lebih baik dibandingkan dengan siswa yang mendapatkan pembelajaran IPS secara konvensional? (2) Apakah peningkatan self esteem siswa setelah mendapatkan pembelajaran dengan multimedia lebih baik dibandingkan dengan siswa yang mendapatkan pembelajaran IPS secara konvensional? (3) Apakah terdapat hubungan yang positif antara hasil belajar IPS siswa dan self esteem siswa dalam pembelajaran yang menggunakan pembelajaran dengan multimedia?

Sejalan dengan rumusan masalah, secara umum penelitian ini bertujuan untuk membandingkan pencapaian dan peningkatan hasil belajar IPS yang pembelajarannya menggunakan multimedia dan konvensional, menganalisis perbedaanself esteem siswa yang pembelajaran dengan multimedia dan konvensional, dan menganalisis hubungan antara hasil belajar IPS siswa dan self esteem siswa dalam pembelajaran yang menggunakan pembelajaran dengan multimedia.

\section{B. TINJAUAN PUSTAKA}

Menurut Sudjana (2005:22) hasil belajar adalah kemampuan-kemampuan yang dimiliki siswa setelah ia menerima pengalaman belajar.Hasil belajar dalam penelitian ini adalah berupa skor pretes dan postes yang merupakan kemampuan siswa setelah menerima pengalaman belajar secara kognitif dengan indikator yang digunakan yaitu pengetahuan, pemahaman, aplikasi, analisis, evaluasi, dan kreativitas.

Rosenberg (Al Hadad, 2010) berpandangan bahwa self-esteem adalah suatu orientasi positif atau negatif seseorang terhadap dirinya sendiri atau dapat pula dikatakan suatu evaluasi yang menyeluruh tentang bagaimana sesorang menilai dirinya.Self-esteem yang dimaksud dalam penelitian ini adalah penilaian siswa terhadap kemampuan, keberhasilan, kemanfaatan, dan kebaikan diri mereka sendiri dalam IPS.Self esteem merupakan fenomena perkembangan yang mulai banyak diteliti. Self Esteem telah diteliti oleh Al Hadad (2010) dan Wahyuni (2012). Wahyuni (2012) meneliti self-esteem dan menemukan peningkatan Self-esteem siswa dalam matematika yang memperoleh pembelajaran ARIASlebih baik daripada siswa yang memperoleh pembelajaran kovensional. Selain itu terdapat hubungan yang positif 
antara kemampuan representasi matematis dengan self-esteem siswa dalam matematika. Namun terdapat hal yang berbeda yang ditemukan oleh Al Hadad (2010), Al Hadad menemukan bahwa Self-esteem siswa dalam matematika setelah melakukan pembelajaran dengan pendekatan Open Ended, tidak lebih baik dibandingkan sebelumnya ditinjau dari keseluruhan siswa. Tetapi bila dilihat dari level sekolah, ternyata self-esteem siswa dalam matematika pada level sekolah tinggi lebih baik setelah melakukan pembelajaran dengan pendekatan Open Ended.

Pembelajaran dengan menggunakan berbagai macam media yang terdiri dari teks, grafik, gambar, animasi, audio, bahkan video dan sebagainya yang mana berfungsi untuk membantu guru dalam menyampaikan materi yang akan disampaikan. Multimedia yang digunakan peneliti untuk mengatasi permasalahan yaitu dengan memanfaatkan lingkungan sekitar siswa, berbagai gambar, video yang dibantu dengan penggunaan aplikasi komputer. Media ini dapat menjadi konkrit bagi siswa sehingga proses pembelajaran lebih bermakna.

Pembelajaran dengan multimedia telah dilakukan oleh beberapa peneliti diantaranya adalah Rohman Y. Abdul (2010) dan Nani Suryani (2012). Rohman Y. Abdul (2010) dalam penelitiannya menyimpulkan bahwa, penggunaan media interaktif dalam pembelajaran dapat meningkatkan hasil belajar siswa. Karena penggunaan media interaktif selama pembelajaran siswa menjadi lebih aktif dan termotivasi dalam kegiatan pembelajaran. Nani Suryani (2012) dalam penelitiannya menyimpulkan bahwa terdapat perbedaan hasil belajar antara kelas eksperimen yang menggunakan MMI dengan kelas kontrol yang menggunaan media Film. Dengan demikian, maka penggunaan MMI memiliki pengaruh yang signifikan terhadap hasil belajar siswa khususnya pada mata pelajaran Geografi. Dari kedua hasil penelitian di atasmenyatakan bahwa penggunaan multimedia (berbagai macam media) dapat meningkatkan hasil belajar siswa, maka dari itu peneliti tertarik untuk meneliti penggunaan multimedia dalam pembelajaran pada mata pelajaran IPS di kelas IV SD.

\section{METODE PENELITIAN}

penelitian ini dilakukan di kelas IV SDN Cipadung yang ada di Kecamatan Cibiru Kota Bandung. Populasi dalam penelitian ini yaitu seluruh siswa kelas IV SDN Cipadungdan yang menjadi sampel dalam penelitian ini adalah kelas IVC sebagai kelas eksperimen sebanyak 36 siswa dan kelas IVA sebagai kelas kontrol sebanyak 35 siswa. Sampel yang dipilih dengan ketentuan kemampuan siswa yang heterogen, artinya siswa dalam satu kelas terdiri dari siswa yang mempunyai kemampuan akademik tinggi, sedang, dan rendah.

Penelitian ini adalah penelitian kuantitatif dengan metode kuasi eksperimen(Quasi Experimental Desains)dengan desain kelompok kontrol non ekivalen. Seperti pada diagram berikut :

Kelas eksperimen : $\mathrm{O} \quad \mathrm{X} \quad \mathrm{O}$

Kelas kontrol : Ō' O $\quad$ (Ruseffendi, 2005: 47)

dengan instrumen penelitian yang digunakan berupa tes hasil belajar IPS dan nontes (self esteem). 


\section{HASIL PENELITIAN DAN PEMBAHASAN}

Pembahasan hasil penelitian ini berdasarkan faktor-faktor yang diamati dan ditemukan dalam penelitian.

\section{Peningkatan Hasil Belajar IPS}

Berikut gambaran umum hasil belajar IPS siswa sebelum dan sesudah pembelajaran.

\section{Tabel 1}

Statistika DeskriptifHasil Belajar

\begin{tabular}{|c|c|c|c|c|c|c|c|}
\hline \multirow{3}{*}{ Variabel } & & \multicolumn{3}{|c|}{ Kelas Multimedia } & \multicolumn{3}{c|}{ Kelas Konvensional } \\
\cline { 3 - 8 } & & Pretes & Postes & $\begin{array}{c}\text { N-Gain } \\
\text { Tes }\end{array}$ & Pretes & Postes & $\begin{array}{c}\text { N-Gain } \\
\text { Tes }\end{array}$ \\
\hline \multirow{4}{*}{ Hasil Belajar } & $\mathrm{n}$ & 36 & 36 & 36 & 35 & 35 & 35 \\
\cline { 2 - 8 } & $x_{\text {maks }}$ & 10 & 19 & 0,92 & 9 & 20 & 1 \\
\cline { 2 - 8 } & $x_{\min }$ & 2 & 11 & 0,4 & 2 & 6 & 0,08 \\
\cline { 2 - 8 } & $\bar{x}$ & 5,86 & 16,33 & 0,74 & 6,31 & 12,8 & 0,47 \\
\cline { 2 - 8 } & $\mathrm{s}$ & 2,13 & 1,99 & 3,71 & 1,98 & 2,97 & 0,20 \\
\hline
\end{tabular}

Berdasarkan Tabel 1 memperlihatkan bahwa rataan skor hasil belajar IPS siswa kelas eksperimen sebelum pembelajaran lebih kecil dibandingkan dengan siswa kelas kontrol, yaitu rataan skor kelas eksperimen 5,86 sedangkan rataan skor kelas kontrol 6,31 dari kedua data tersebut diperoleh selisih sebesar 0,45 (seperti terlihat pada Tabel1). Selisih data dari kedua kelas tersebut tidak terlalu besar, dapat diduga bahwa kedua kelas memiliki kemampuan awal hasil belajar yang tidak jauh berbeda.

Setelah pembelajaran dilaksanakan, rataanhasil belajar siswa kelas ekperimen yaitu 16,33 , dengan standar deviasinya 1,99 . Sementara itu rata-rata skor postes kelas kontrol yaitu 12,8 dengan standar deviasinya 2,97. Berdasarkan standar deviasi skor postes kelas eksperimen dan kelas kontrol, dapat dilihat bahwa penyebaran hasil belajarsetelah adanya pembelajaran untuk kelas eksperimen kurang menyebar daripada kelaskontrol. Hal ini dikarenakan standar deviasi kelas eksperimen terlihat lebih kecil dibandingkan standar deviasi kelas kontrol.

Sedangkan N-gain hasil belajar IPS siswa, dapat dilihat bahwa rata-rata N-gain untuk hasil belajar kelas eksperimen sebesar 0,74 dan untuk kelas kontrol sebesar 0,47, dari kedua data tersebut terlihat bahwa rata-rata kelas eksperimen N-gainnya lebih besar daripada kelas kontrol, dapat diduga bahwa kelas eksperimen memiliki peningkatan hasil belajar yang lebih baik dari pada kelas kontrol.Berikut disajikan secara visual rata-rata N-gain Hasil Belajar IPS. 


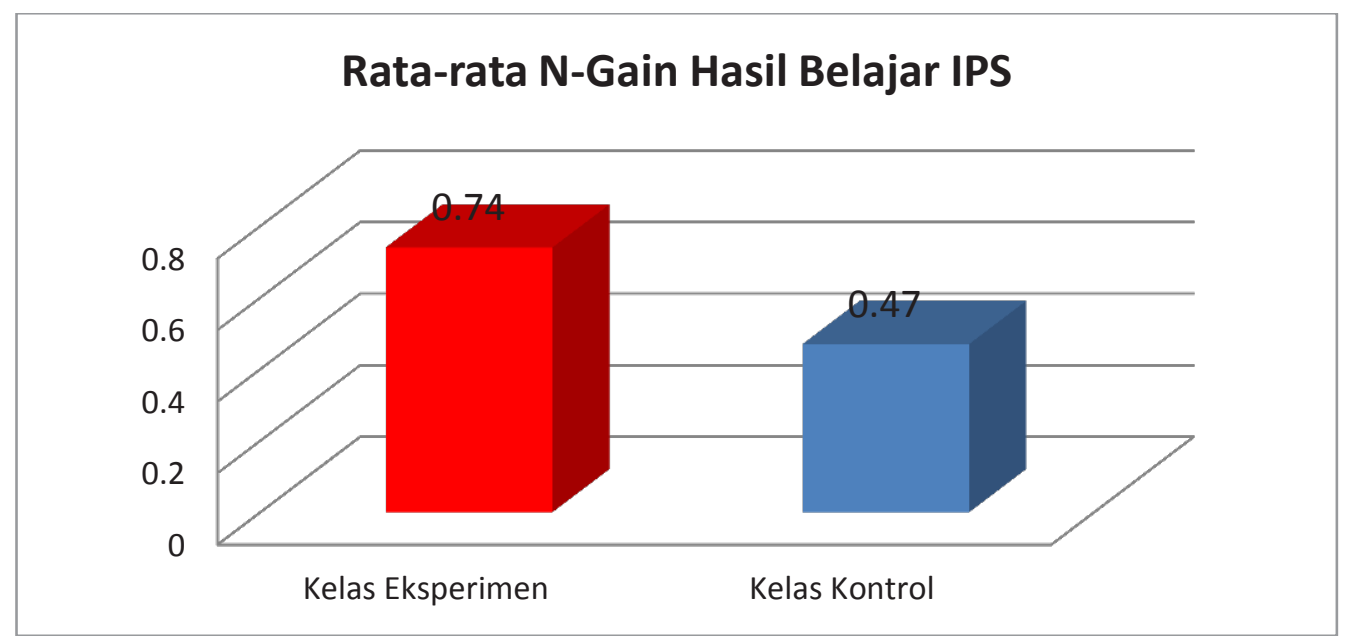

Gambar 1

Rata-rata N-Gain Hasil Belajar IPS

Dari hasil penelitian dan analisis data yang telah dilakukan dibandingkan dengan pembelajaran konvensional, pembelajaran dengan menggunakan multimedia ini menunjukkan peran yang berarti dalam meningkatkan hasil belajar IPS siswa.Hal itu dikarenakan pada proses pembelajaran menggunakan multimedia fokus kegiatan belajar berasa sepenuhnya pada siswa dan selama kegiatan pembelajaran berlangsung siswa lebih tertarik dalam mengikuti kegiatan belajar. Penggunaan multimedia membuat siswa terkondisi untuk mengkonstruksi pengetahuannya secara mandiri. Selain itu, penggunaan berbagai gambar animasi, video serta suara yang terdapat pada multimedia sangat membantu siswa dalam memahami konsep yang dipelajari.

Berdasarkan hasil pengamatan selama treatment dilakukan, terdapat beberapa hal yang mempengaruhi perbedaan hasil belajar IPS siswa yang belajar menggunakan multimedia dengan siswa yang belajar menggunakan pembelajaran biasa. Hal yang paling utama ialah bahwa adanya media dalam suatu pembelajaran dapat membantu pemahaman siswa mengenai konsep IPS yang abstrak. Konsepkonsep yang abstrak tersebut dapat dibuat menjadi lebih nyata dengan bantuan gambar atau benda nyata yang ada di lingkungan sekitar siswa sebagai media. Terlebih menggunakan multimedia yang didalamnya terdapat berbagai gambar, video, suara yang lebih dekat dengan kehidupan nyata.

Penggunaan mulitimedia dalam pembelajaran IPS dapat memberikan gambaran yang lebih nyata dari konsep IPS yang abstrak. Salah satunya adalah dalam mempelajari konsep masalah sosial, pemahaman siswa tidak akan bermakna apabila guru hanya memberikan penjelasan materi secara langsung kepada siswa, karena siswa diharuskan memecahkan permasalahan yang ada sesuai dengan kondisi yang nyata. Namun dengan ilustrasi yang ada dalam multimedia, siswa akan sangat terbantu dalam proses belajar. Contohnya adalah dengan bantuan video mengenai masalah banjir yang berkaitan dengan masalah sosial sampah, dalam video tersebut terkandung indikator yang akan dipelajari siswa seperti penyebab terjadinya banjir dan solusi untuk mengantisipasi banjir sehingga siswa akan terangsang untuk mengungkapan pendapatnya dari video yang dilihatnya. Dengan 
multimedia tersebut pemahaman siswa mengenai IPS yang abstrak akan semakin kuat, selain siswa mengingat dan menghafal suatu konsep yang sedang ia pelajari, siswa juga diberi gambaran yang nyata mengenai konsep IPS yang abstrak tersebut.

Selain itu, faktor lainnya adalah aktivitas guru pada pembelajaran dengan multimedia cenderung hanya sebagai fasilitator dan mediator, sehingga siswa lebih leluasa untuk beraktivitas dan berinteraksi dalam proses pembelajaran. Sedangkan pada kelas kontrol guru benar-benar sebagai pemberi informasi dan hanya beberapa siswa saja yang aktif dalam proses pembelajaran.

Dengan demikian, hasil penelitian ini sejalan dengan penelitian dari Rohman yang menggunakan media interaktif pada mata pelajaran geografi berhasil meningkatkan hasil belajar siswa, dan penelitian yang dilakukan oleh penulis dalam mata pelajaran IPS di kelas IV SD berhasil meningkatkan hasil belajar siswa. Maka dari itu penggunaan multimedia selama proses pembelajaran IPS berpengaruh terhadap hasil belajar siswa di kelas IV SD.

\section{PeningkatanSelf-Esteem Siswa}

Selanjutnya adalah deskriptif data skor Self Esteem siswa disajikan pada Tabel 2.

Tabel 2

Statistika DeskriptifSelf Esteem

\begin{tabular}{|c|c|c|c|c|c|c|c|}
\hline \multirow{3}{*}{ Variabel } & & \multicolumn{3}{|c|}{ Kelas Multimedia } & \multicolumn{3}{c|}{ Kelas Konvensional } \\
\cline { 3 - 8 } & & Pretes & Postes & $\begin{array}{c}\text { N-Gain } \\
\text { Tes }\end{array}$ & Pretes & Postes & $\begin{array}{c}\text { N-Gain } \\
\text { Tes }\end{array}$ \\
\hline \multirow{4}{*}{ Self Esteem } & $\begin{array}{c}\text { Angket } \\
\text { Awal }\end{array}$ & $\begin{array}{c}\text { Angket } \\
\text { Akhir }\end{array}$ & $\begin{array}{c}\text { N-Gain } \\
\text { Angket }\end{array}$ & $\begin{array}{c}\text { Angket } \\
\text { Awal }\end{array}$ & $\begin{array}{c}\text { Angket } \\
\text { Akhir }\end{array}$ & $\begin{array}{c}\text { N-Gain } \\
\text { Angket }\end{array}$ \\
\cline { 2 - 8 } & $\mathrm{n}$ & 36 & 36 & 36 & 35 & 35 & 35 \\
\cline { 2 - 8 } & $x_{\text {maks }}$ & 80,82 & 104,30 & 0,67 & 84,88 & 96,85 & 0,60 \\
\cline { 2 - 8 } & $x_{\text {min }}$ & 58,53 & 82,68 & 0,23 & 61,72 & 74,38 & 0,07 \\
\cline { 2 - 8 } & $\bar{x}$ & 71,62 & 93,64 & 0,49 & 73,53 & 86,28 & 0,29 \\
\cline { 2 - 8 } & $\mathrm{s}$ & 6,44 & 5,79 & 0,12 & 5,31 & 5,50 & 0,12 \\
\hline
\end{tabular}

Dari tabel di atas, skor rata-rata self esteemawal siswa diperoleh skor untuk kelas eksperimen sebesar 71,62 dan kelas kontrol sebesar 73,53, dari kedua data tersebut diperoleh selisih sebesar 1,91. Selisih data ini pun tidak terlalu besar, maka dapat diduga pula bahwa kedua kelas memiliki self esteemawal yang tidak jauh berbeda. Untuk skor rata-rata self esteemakhir siswa diperoleh skor untuk kelas eksperimen sebesar 93,64 dan kelas kontrol sebesar 86,28, dari kedua data tersebut diperoleh selisih sebesar 7,36.

Sedangkan $\mathrm{N}$-gain self esteem siswa, dapat dilihat bahwa rata-rata $\mathrm{N}$-gain untuk self esteem kelas eksperimen sebesar 0,49 dan untuk kelas kontrol sebesar 0,29, dari kedua data tersebut terlihat bahwa rata-rata kelas eksperimen $\mathrm{N}$-gainnya lebih besar daripada kelas kontrol, dapat diduga bahwa kelas eksperimen memiliki peningkatan self esteem yang lebih baik dari pada kelas kontroldimungkinkan terjadi 
karena adanya pembelajaran yang dilakukan. Berikut disajikan secara visual ratarata N-gain self esteem siswa.

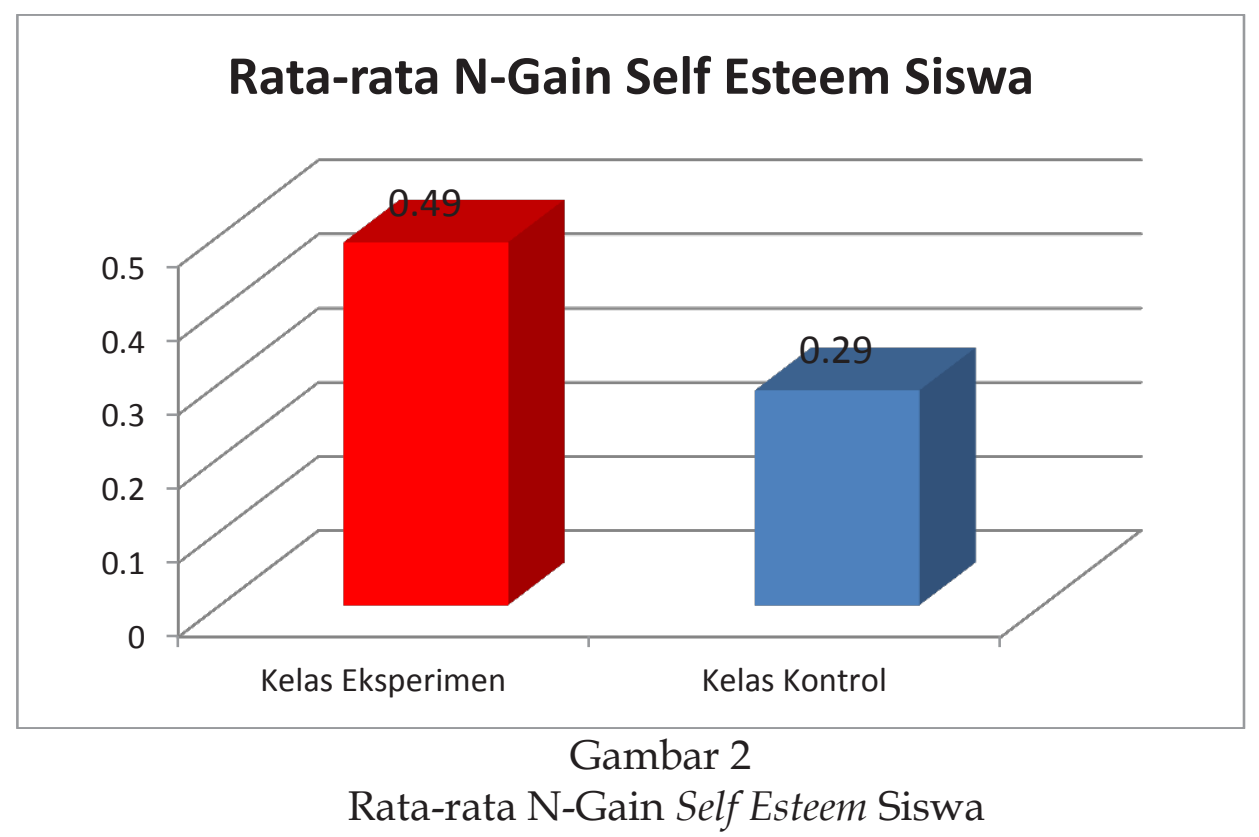

Hasil penelitian menunjukkan bahwa peningkatan self esteem siswa kelas eksperimen lebih baik daripada peningkatan self esteem kelas kontrol. Artinya pembelajaran yang menggunakan pembelajaran multimedia memberikan pengaruh yang baik kepada perkembangan self esteem siswa. Hal ini terjadi karena Self esteem dapat dikembangkan melalui interaksi sosial, siswa dituntut untuk berpartisipasi aktif dalam mengeksplorasi dan menemukan sendiri pengetahuan mereka (melalui kerja kelompok), dan self esteem juga dapat dikembangkan dengan melakukan pembelajaran yang bersifat rasional dan realistis di dalam kelas. Selain itu, siswa dalam kelompok eksperimen memiliki self esteem yang tinggi untuk bertanya kepada guru, berdiskusi, memecahkan permasalahan yang diberikan, mengerjakan soal di depan kelas, berbagi apa yang mereka ketahui, dan lebih menghargai pendapat orang lain serta mampu bekerjasama dengan kelompoknya.

\section{Hubungan Hasil Belajar IPS dan Self-Esteem Siswa}

Tujuan penelitian selanjutnya adalah untuk melihat hubungan antara hasil belajar IPS dan self esteemsiswa dalam pembelajaran baik kelas eksperimen maupun kelas kontrol. Data yang diperoleh dari skor postes hasil belajar IPS kelas eksperimen dan kelas kontrol dengan data angket akhir skala self esteemkelas eksperimen dan kelas kontrol. Sebelum dilakukan uji statistik untuk mencari koefisien korelasi antara hasil belajar IPS dan self esteemsiswa terlebih dahulu dilakukan transformasi data dengan menggunakan Method of Sucessive Interval (MSI) pada data skala self esteem, karena data yang diperoleh merupakan data ordinal maka dilakukan transformasi data menjadi data interval agar kedua jenis kemampuan memiliki data yang sama.

Selanjutnya, masing-masing data diuji normalitasnya terlebih dahulu dan hasil data kelas kontrol berdistribusi normal sedangkan kelas eksperimen tidak 
berdistribusi normal.Untuk mengetahui seberapa kuat hubungan antara hasil belajar IPS dan self esteem siswa kelas kontrol digunakan uji Korelasi Product Moment Pearson dengan taraf signifikansi 0,05. Sedangkan untuk mengetahui seberapa kuat hubungan antara hasil belajar IPS dan self esteem siswa kelas eksperimen digunakan uji Korelasi Spearmen dengan taraf signifikansi 0,05.

Berdasarkan hasil uji statistik menunjukkan bahwa tidak terdapat hubungan yang signifikan antara hasil belajar IPS dan self esteem kelas eksperimen.Hal ini menunjukkan bahwa tidak terdapat hubungan yang saling mempengaruhi antara hasil belajar IPS dan self esteemsiswa. Artinya apabila hasil belajar IPS tinggi belum tentu self esteem siswa tinggi, begitu juga sebaliknya apabila hasil belajar IPS rendah belum tentu self esteem siswa rendah pula.

\section{E. KESIMPULAN DAN SARAN}

Berdasarkan hasil analisis dan pembahasan serta temuan-temuan yang diperoleh dalam penelitian ini, maka dapat disimpulkan beberapa hal sebagai berikut:

1. Peningkatan hasil belajar IPS siswa setelah mendapatkan pembelajaran dengan multimedia lebih baik dibandingkan dengan siswa yang mendapatkan pembelajaran IPS secara konvensional.

2. Peningkatan self esteem siswa setelah mendapatkan pembelajaran dengan multimedia lebih baik dibandingkan dengan siswa yang mendapatkan pembelajaran IPS secara konvensional.

3. Tidak terdapat hubungan yang positif antara hasil belajar IPS siswa dan self esteem siswa dalam pembelajaran yang menggunakan pembelajaran dengan multimedia.

Berdasarkan hasil penelitian dan kesimpulan di atas, maka penulis mengemukakan saran untuk perbaikan di masa mendatang dan dapat bermanfaat untuk perbaikan pada penelitian-penelitian selanjutnya yaitu sebagai berikut:

1. Bagi guru, pembelajaran IPS dengan menggunakan multimedia mampu meningkatkan hasil belajar siswa dibandingkan dengan pembelajaran biasa yang hanya menggunakan satu jenis media. Maka dari itu, multimedia dapat digunakan selama proses pembelajaran berlangsung.

2. Penggunaan multimedia berpengaruh terhadap hasil belajar siswa pada pembelajaran IPS. Oleh karena itu, guru mata pelajaran IPS bisa menerapkannya dalam pembelajaran yang lain, karena dalam pelaksanaannya siswa menjadi aktif dan termotivasi dalam kegiatan pembelajaran. Apabila siswa berantusias dalam mengikuti pembelajaran, maka secara tidak sadar guru pun lebih bersemangat dalam mengajar.

3. Aspek psikologi yang diukur dalam penelitian ini hanya self esteem.self esteem yang ditelaah pada penelitian ini merupakan self esteem yang terkait dengan hasil belajar IPS. Peneliti selanjutnya sebaiknya meneliti aspek psikologi yang lain. 


\section{DAFTAR PUSTAKA}

Al Hadad, S. F. (2010). Meningkatkan Kemampuan Representasi Multipel Matematis dan Self-esteem Siswa SMP melalui Pembelajaran dengan Pendekatan Open Ended. Bandung: Disertasi Doktor SPs UPI: Tidak diterbitkan.

Dahar, W.R. (1988). Teori-Teori Belajar.Jakarta : Erlangga.

Depdiknas, 2004. Materi Pelatihan Terintegrasi Mata Pelajaran IPS. Dirjen Pendidikan Dasar dan Menengah. Jakarta.

Depdiknas. (2006). Kurikulum 2006 standar kompetensi mata pelajaran. Jakarta : Depdiknas.

Rohman, A.A.Y. (2008). Pengaruh Penggunaan Media Interaktif Terhadap Hasil Belajar Siswa pada Mata Pelajaran Geografi". Skripsi Jurusan Pendidikan Geografi UPI : Tidak Diterbitkan.

Suryani, N. (2012). Pengaruh Penggunaan Multimedia Interaktif (MMI) Terhadap Hasil Belajar Siswa. Skripsi Jurusan Pendidikan Pendidikan Geografi UPI: Tidak Diterbitkan.

Ruseffendi, H. E. T. (2005). Dasar-dasar Penelitian Pendidikan E Bidang Non-Eksata Lainnya. Bandung: Tarsito.

Wahyuni, S. (2012). Peningkatan Kemampuan Representasi Matematis dan Self Esteem Siswa Sekolah Menengah Pertama dengan Menggunakan Model Pembelajaran ARIAS. Bandung: Tesis SPs UPI: Tidak diterbitkan. 